\title{
New normal baseline data during nationwide lock down due to Covid 19 pandemic in the world's largest ship recycling yard at Alang, India
}

\author{
Amit Chanchpara ${ }^{1,2} \cdot$ Vasavdutta Sonpal $^{1} \cdot$ Gauravkumar Mehta $^{3} \cdot$ Tarini Prasad Sahoo $^{1}$. \\ Ravikumar Bhagwan Thorat ${ }^{1,2}$. Sanak Ray ${ }^{1,2}$. Soumya Haldar ${ }^{1,2}$ (D)
}

Received: 4 November 2020 / Accepted: 8 February 2021 / Published online: 4 March 2021

(C) The Author(s), under exclusive licence to Springer-Verlag GmbH, DE part of Springer Nature 2021

\begin{abstract}
A detailed study to generate the new normal baseline data has been carried out during nationwide lockdown (May 12 to May 16, 2020) covering sampling for ambient air, coastal water, coastal sediments, fish and bioaccumulation of heavy metals, in an around Alang, the world's biggest ship recycling yard. The lockdown data were compared with 2018 and 2019 observed data. $\mathrm{PM}_{10}$ values during lockdown were reduced by 3.75 to 4.5 times as compared with previous 2 years. Similarly, four-fold reduction of $\mathrm{PM}_{2.5}$ and SPM values was observed during lockdown. The gaseous pollutants like $\mathrm{NO}_{2}$ and $\mathrm{O}_{3}$ are within safe limit. Overall air quality index (AQI) improved significantly during lockdown. Similarly, there was drastic reduction in the majority of the nutrient parameters in the coastal water. Different heavy metal concentration in the coastal sediments samples also showed strong reduction during lockdown sampling in comparison with other two sampling. This proves that the coastal environment has its efficient self-cleaning potentials if there is considerable reduction in the anthropogenic as well as industrial activities. Diversity of phytoplankton and zooplankton also increased. The results were validated using statistical techniques like analysis of variance and least significance difference (LSD).
\end{abstract}

Keywords Air quality $\cdot$ Seawater $\cdot$ Sediment $\cdot$ Pollution $\cdot$ Biological diversity $\cdot$ LSD

\section{Introduction}

Indian ship building industry started in the ancient era as early as 2600-3000 BC. However, with the time and increase rate of civilization, the requirement for the iron and steel increased. This is the primary reason for genesis of the world's largest ship

Amit Chanchpara and Vasavdutta Sonpal contributed equally to this work.

Responsible Editor: Philippe Garrigues

Sanak Ray

sanakray@csmcri.res.in

$\triangle$ Soumya Haldar

shaldar@csmcri.res.in

1 Analytical and Environmental Science Division \& Centralized Instrument Facility, CSIR-Central Salt \& Marine Chemicals Research Institute, G.B. Marg, Bhavnagar 364002, India

2 Academy of Scientific and Innovative Research (AcSIR), Ghaziabad 201002, India

3 Environment Cell, Gujarat Maritime Board, Gandhinagar 382010, India recycling yard at Alang before four decades. This ship recycling yard has grown considerably since its inception in 1982-1983. In the last 15 years, a total of 3906 ships corresponding to 33.806 MMT of light displacement tonnage (LDT) (GMB report, www. gmbports.org) were recycled. However, no baseline environmental data have been recorded prior to the inception of the yard. Generally, when ships arrive at Alang for dismantling, they contain complex materials including hazardous substances embedded with structure of the ships, which need to be disposed in environmentally safe and sound manner. Gujarat Maritime Board (GMB) is the overall custodian of the Alang-Sosiya Ship Recycling Yard. GMB has developed dedicated treatment, storage and disposal facility (TSDF) site, and it is in operation made functional since 2006 for management of wastes generated from the ship recycling. The TSDF site consists landfill cells for hazardous and non-hazardous solid wastes, bilge water treatment plant and high temperature incinerator. Further, GMB also involved CSIR-Central Salt and Marine Chemicals Research Institute (CSIR-CSMCRI) to generate baseline data from ambient air, water and sediments with respect to both chemicals as well as biological parameters for last 2 years in Alang ship recycling area. To further safeguard the environmental law, 
India recently approved Ship Recycling Act (2019) and ratified the International Maritime Organization's (IMO) Hong Kong Convention to undermining existing laws; this will strengthen the environmental quality of Alang along with improved safeguard against the work force at different ship recycling units.

Due to Covid-19 pandemic, along with whole country, all the ship recycling activity of the Alang ship recycling yard has been stand stilled from the month of March, 2020. Complete lockdown was continued up to end of May, 2020. This lockdown has created a unique opportunity to collect environmental data (Saraswat and Saraswat 2020). In 2006, Union Cabinet passed National Environmental Policy under which Environment Impact Assessment (EIA) followed by proper environmental management plan (EMP) becomes mandatory requirement for setting up of any new industry or modernization or expansion. However, such study and data were not required at the time of setting up of Alang ship recycling yard almost four decades ago. Complete lockdown has given environmentalists a lifetime opportunity to collect baseline data in the Alang ship recycling yard in comparison with the situation when there was no existence of this industry (Hanson et al. 1993). The comparison of the present data (May 2020) with recent past (February 2018, January 2019) data will give an opportunity to track the source of different pollution and this can be considered baseline data in new normal condition. Comparison of all the data may help to generate environmental standard for ship recycling yard across the world.

To generate the new normal baseline data, CSIRCSMCRI has carried out a detailed snapshot environmental sampling during nationwide lockdown (May 12 to May 16, 2020) covering ambient air, coastal water, coastal sediments and fish bioaccumulation of heavy metals, in an around Alang ship recycling yard with respect to both physicochemical as well as biological parameters. The data has also been compared with last 2 years' baseline data to understand the impact of lockdown on total environment of Alang. Up to our understanding, this study will be important documents to understand the pollution sources in different ship recycling yards worldwide and will ultimately help to formulate long-term management measures.

\section{Material and methods}

\section{Selection of sampling locations}

\section{Ambient air}

For air sampling, four sampling stations were selected inside Alang Ship recycling yards in coordination with the previous two samplings undertaken in January 2019 and February 2018. All stations were located in different plots at Alang with an average distance of $2-3 \mathrm{~km}$, and no recycling activities were performed since March, 2020 (Table 1 and Fig. 1).

\section{Seawater and sea sediments}

Seawater was collected from total of 5 sampling stations from the intertidal area of ship recycling yards spread nearly $10 \mathrm{~km}$ area. Sea sediments were collected from three stations overlapping to the water sampling stations. Sediments were not collected from two remaining stations due to rocky substratum. All the sampling stations were mentioned in the Tables 2, 3 , and 4 and Fig. 1.

\section{Method of analysis}

\section{Ambient air}

Ambient air sampling was carried out weekly two times continuously for $24 \mathrm{~h}$. The averages of two values were represented. Due to restriction in movement, only weekly two samples were collected in 2020. However, in the previous 2 years, ambient air samples were carried out for a complete month in each season for three times (pre-monsoon, post-monsoon and winter) in years. Average values of all the data were represented in this manuscript.

\section{Particulate matters}

Measurement of $\mathrm{PM}_{10}$ was done as per the method described in Indian standard (Kisan et al. 2006). In brief, measured volume of air $(1132 \mathrm{~L} / \mathrm{min})$ is drawn through Whatman filter paper $(20.3 \times 25.4 \mathrm{~cm})$. Particles with aerodynamic diameter less than the cut-point of the inlet size are collected by the filter. $\mathrm{PM}_{10}$ value is measured by weight gain in filter paper divided by the total air filtered. Limit of detection is between 10 and $1200 \mu \mathrm{g} / \mathrm{m}^{3}$.

\section{Suspended particulate matters and $\mathrm{PM}_{2.5}$}

Both suspended particulate matters (SPM) and $\mathrm{PM}_{2.5}$ were measured using high volume samplers using appropriate collector and filter papers, respectively, by following $\mathrm{CPCB}$ guideline (CPCB 2013).

\section{Heavy metals, benzene and benzo pyrine}

For heavy metal analysis, filter paper (half of filter paper, size $8^{\prime \prime} \times 10^{\prime \prime}$ ) was digested in acid, and sample was prepared as per the method described in EPA compendium method IO 3 (USEPA 1999). Finally, the heavy metals were analysed in ICP-MS (iCAP RQ). For benzene and benzo pyrine, filter 
Table 1 Ambient air quality values observed during the study period at different locations

\begin{tabular}{|c|c|c|c|c|c|c|c|c|c|}
\hline Location & & A1 & $\mathrm{A} 2$ & A3 & A4 & Mean & STD & Max & Min \\
\hline \multirow[t]{3}{*}{$\mathrm{PM}_{10}\left(\mu \mathrm{g} / \mathrm{m}^{3}\right)$} & May 20 & 34.2 & 44.2 & 38.6 & 37.5 & 38.63 & 4.16 & 44.2 & 34.2 \\
\hline & January 19 & 115.5 & 152 & 155 & 159 & 145.38 & 20.12 & 159 & 115.5 \\
\hline & February 18 & 167 & 160 & 195 & 173.5 & 173.88 & 15.12 & 195 & 160 \\
\hline \multirow[t]{3}{*}{$\mathrm{PM}_{2.5}\left(\mu \mathrm{g} / \mathrm{m}^{3}\right)$} & May 20 & 20.5 & 25.9 & 27.4 & 29.6 & 25.85 & 3.88 & 29.6 & 20.5 \\
\hline & January 19 & 74 & 89.5 & 136 & 104 & 100.88 & 26.43 & 136 & 74 \\
\hline & February 18 & 92.5 & 78.5 & 135.5 & 96.5 & 100.75 & 24.42 & 135.5 & 78.5 \\
\hline \multirow[t]{3}{*}{$\mathrm{SPM}\left(\mu \mathrm{g} / \mathrm{m}^{3}\right)$} & May 20 & 60.2 & 59.3 & 57.1 & 62.3 & 59.73 & 2.15 & 62.3 & 57.1 \\
\hline & January 19 & 237 & 198 & 211 & 245.5 & 222.88 & 22.14 & 245.5 & 198 \\
\hline & February 18 & 235 & 253 & 213 & 249.5 & 237.63 & 18.17 & 253 & 213 \\
\hline \multirow[t]{3}{*}{$\mathrm{SO}_{2}\left(\mu \mathrm{g} / \mathrm{m}^{3}\right)$} & May 20 & 17.3 & 15.9 & 20.4 & 19.4 & 18.25 & 2.03 & 20.4 & 15.9 \\
\hline & January 19 & 78 & 80.3 & 87.1 & 80.7 & 81.53 & 3.9 & 87.1 & 78 \\
\hline & February 18 & 87.6 & 93.1 & 90.6 & 76.55 & 86.96 & 7.3 & 93.1 & 76.55 \\
\hline \multirow[t]{3}{*}{$\mathrm{NO}_{2}\left(\mu \mathrm{g} / \mathrm{m}^{3}\right)$} & May 20 & 11.5 & 10.8 & 13.8 & 14.9 & 12.75 & 1.92 & 14.9 & 10.8 \\
\hline & January 19 & 81 & 80 & 74.2 & 76.45 & 77.91 & 3.15 & 81 & 74.2 \\
\hline & February 18 & 89.45 & 87.05 & 89.05 & 78.75 & 86.08 & 4.99 & 89.45 & 78.75 \\
\hline \multirow[t]{3}{*}{$\mathrm{NH}_{3}\left(\mu \mathrm{g} / \mathrm{m}^{3}\right)$} & May 20 & 7.8 & 7.6 & 8.2 & 7.6 & 7.8 & 0.28 & 8.2 & 7.6 \\
\hline & January 19 & 37.35 & 44.5 & 41.95 & 32.85 & 39.16 & 5.14 & 44.5 & 32.85 \\
\hline & February 18 & 33.55 & 41.75 & 46.95 & 36.8 & 39.76 & 5.86 & 46.95 & 33.55 \\
\hline \multirow[t]{3}{*}{$\mathrm{O}_{3}\left(\mu \mathrm{g} / \mathrm{m}^{3}\right)$} & May 20 & 0 & 5.8 & 7.6 & 5.9 & 4.83 & 3.32 & 7.6 & 0 \\
\hline & January 19 & 24.25 & 31.7 & 44.55 & 37.1 & 34.4 & 8.58 & 44.55 & 24.25 \\
\hline & February 18 & 28 & 35.9 & 48.5 & 39.7 & 38.03 & 8.52 & 48.5 & 28 \\
\hline \multirow[t]{3}{*}{ As $\left(\mathrm{ng} / \mathrm{m}^{3}\right)$} & May 20 & ND & ND & ND & ND & ND & ND & ND & ND \\
\hline & January 19 & 1.175 & ND & 1.905 & 1.06 & 1.04 & 0.78 & 1.91 & ND \\
\hline & February 18 & 1.3 & ND & 2.4 & 1.245 & 1.24 & 0.98 & 2.4 & ND \\
\hline \multirow[t]{3}{*}{$\mathrm{Ni}\left(\mathrm{ng} / \mathrm{m}^{3}\right)$} & May 20 & 1.02 & ND & $\mathrm{ND}$ & 1.54 & 0.64 & 0.77 & 1.54 & ND \\
\hline & January 19 & 2.175 & 2.71 & 3.535 & 2.065 & 2.62 & 0.67 & 3.54 & 2.07 \\
\hline & February 18 & 1.68 & 1.225 & 1.83 & 1.945 & 1.67 & 0.32 & 1.95 & 1.23 \\
\hline \multirow[t]{3}{*}{$\mathrm{Pb}\left(\mu \mathrm{g} / \mathrm{m}^{3}\right)$} & May 20 & ND & ND & 1.02 & ND & 0.26 & 0.51 & 1.02 & 0 \\
\hline & January 19 & ND & ND & ND & ND & ND & ND & ND & ND \\
\hline & February 18 & 1.135 & ND & 2.28 & 1.92 & 1.33 & 1.01 & 2.28 & ND \\
\hline \multirow[t]{3}{*}{ Benzene $\left(\mu \mathrm{g} / \mathrm{m}^{3}\right)$} & May 20 & 0 & 1.06 & 0 & 1.56 & 0.66 & 0.78 & 1.56 & 0 \\
\hline & January 19 & 3.35 & 1.98 & 4.105 & 3.25 & 3.17 & 0.88 & 4.11 & 1.98 \\
\hline & February 18 & 2.11 & 1.69 & 2.87 & 2.345 & 2.25 & 0.49 & 2.87 & 1.69 \\
\hline \multirow[t]{3}{*}{ Benzo(a)Pyrene (BaP) (ng/m³) } & May 20 & ND & ND & ND & ND & ND & ND & ND & ND \\
\hline & January 19 & ND & ND & ND & ND & ND & ND & ND & ND \\
\hline & February 18 & ND & ND & ND & ND & ND & ND & ND & ND \\
\hline
\end{tabular}

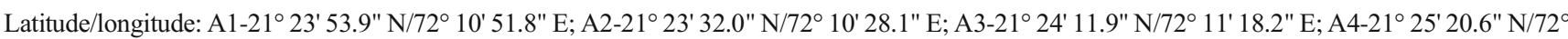
$12^{\prime} 35.3^{\prime \prime} \mathrm{E}$

$N D$ not detected

papers were dipped organic solvent (toluene), and the analysis was carried out in GCMS following the method described in BIS method IS 5182 (part 12):2004.

\section{Sulphur dioxide, nitrogen dioxide, ammonia and ozone}

From ambient air samples, $\mathrm{SO}_{2}$ in is analysed based on IS 5182 (part 2): 2001 method with detection limit of 10 to $100 \mu \mathrm{g} / \mathrm{m}^{3}, \mathrm{NO}_{2}$ was analysed based on IS 5182 (part 6): 2006 method with detection limit of 5 to 500 $\mu \mathrm{g} / \mathrm{m}^{3}$, ammonia was analysed based on the method described in (CPCB 2013) with detection limit of 5 to $100 \mu \mathrm{g} / \mathrm{m}^{3}$ and $\mathrm{O}_{3}$ was analysed based on IS 5182 (part 9): 1974 RA 2009 method with detection limit of 5 to $100 \mu \mathrm{g} / \mathrm{m}^{3}$.

\section{Seawater and sediments}

\section{Physicochemical parameters}

Analysis of different physicochemical parameters of seawater samples i.e. $\mathrm{pH}$, temperature, total suspended solids (TSS), turbidity, dissolved oxygen (DO), biochemical oxygen demand (BOD), nitrite $\left(\mathrm{NO}_{2}\right)$, nitrate $\left(\mathrm{NO}_{3}\right)$, ammonia $\left(\mathrm{NH}_{3}\right)$, phosphate $\left(\mathrm{PO}_{4}\right)$ and silicate were done as per our previous paper (Haldar et al. 2014) following the detailed methods described in APHA (2005).

\section{Biological parameters}

Phytoplankton samples were concentrated by centrifugation followed by transfer of $1 \mathrm{ml}$ on to the Sedgewick Rafter counting chamber under a microscope (Olympus 

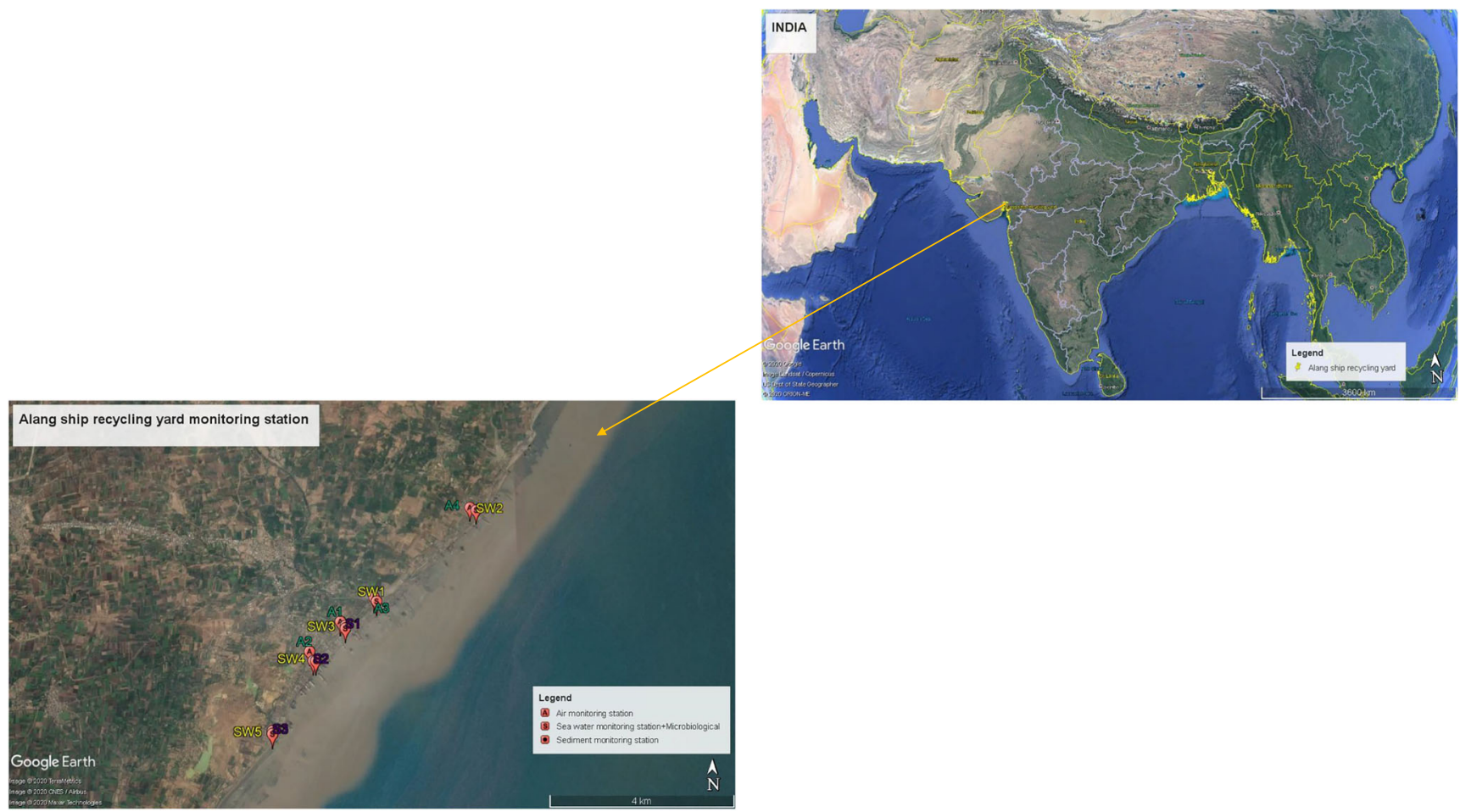

Fig. 1 Topography of sampling (air, seawater and sediment) locations during the study

IX 70), and phytoplankton count was expressed as number of cells per litter of seawater sample.

\section{Heavy metals from seawater and sea sediment}

Heavy metals samples were analysed as per the method 3125B: 2017 (ICP-MS) described in APHA (2017).

\section{Statistical analysis}

\section{Analysis of variance}

The analysis of variance (ANOVA) in one way classification using the null hypothesis technique was used to determine whether any significant difference is existing between different groups (May 2020, January 2019 and February 2018). The different groups were considered based upon different ambient air quality parameters, seawater and sediments parameters. The above test was carried out using Microsoft Office Excel 2010 for validation of observed data during the study (Ray et al. 2019).

\section{Least significance difference}

The least significant difference (LSD) is carried out to determine the significant difference between pairs of different groups (May 2020 and January 2019; May 2020 and February 2018; January 2019 and February 2018). Instead of calculating $t$ for each pair, we calculated the LSD at the desired level of significance $(\alpha=0.05)$. The LSD was calculated using Microsoft Office Excel 2010 for validation of observed data during the study (Jena et al. 2013).

The experimental data were collected in triplicates, and the mean was considered for interpretation. The experimental error was within $\pm 5 \%$. The mean and standard deviation was calculated using Microsoft Office Excel 2010.

\section{Results and discussion}

\section{Ambient air quality}

\section{Particulate matter}

Environmental pollution is a concern of the for environment for the maritime transport and ship recycling industries. In European countries, shipping emission contributes with 1$7 \%$ of ambient air $\mathrm{PM}_{10}$ levels, $1-14 \%$ of $\mathrm{PM}_{2.5}$ and $7-24 \%$ of $\mathrm{NO}_{2}$ level in the coastal environment (Viana et al. 2014).

There is a significant $(p<0.05)$ reduction of all the particulate matters (PM) in the ambient air during lock down period in comparison with the sample collection during 2019 and 2018 (Fig. 2a). It is true that the sampling time was not same in three samplings, but all the three samplings reported (2018, 2019 and 2020) were carried out during premonsoon, and according to the Indian metrological data (IMD), there was 
Table 2 Comparative description of average air quality index (AQI) of ambient air quality monitoring stations at Alang

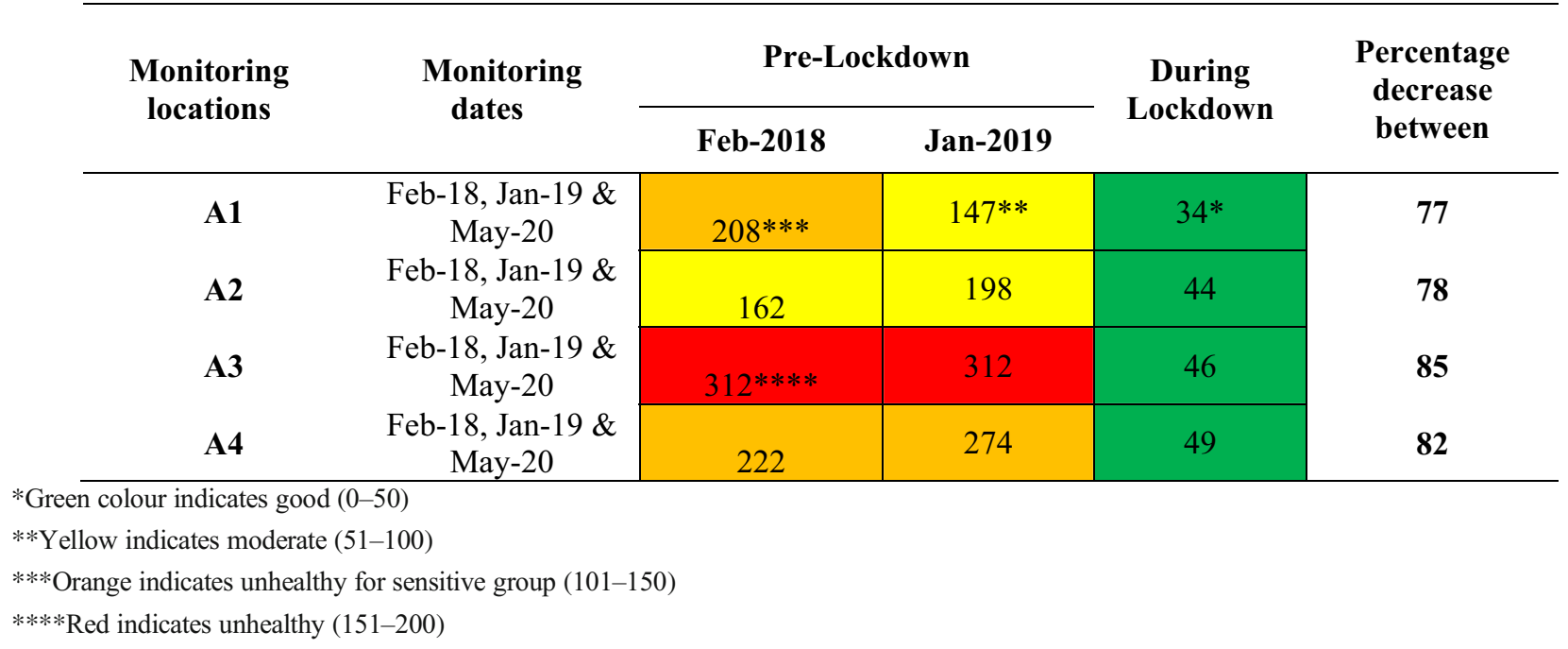

no precipitation during the sampling time. It was observed that the $\mathrm{PM}_{10}$ value of lockdown period was reduced by 3.75 to 4.5 times in comparison with the average value obtained during two previous years (Table 1$)$. There is a significant $(p<$ 0.05 ) reduction (four-fold) in the average value of $\mathrm{PM}_{2.5}$ also during lockdown sampling. Decrease in PM concentration directly correlates with decrease in mortality and morbidity rate. A decrease of $10 \mu \mathrm{g} / \mathrm{m}^{3}$ of $\mathrm{PM}_{10}$ levels resulted $3-6 \%$ decrease in visit of asthma patent and 1-3\% decrease in visit of upper respiratory disease not with asthma to hospital (Gordian et al. 1996). Alang hospital data revealed that OPD patient numbers decreased considerably from 26292 in 20182019 to 19,072 in 2019-1920 (www.gmbports.org). Among total OPD, the number of chest patients is generally low in Alang (varied from 24 to 91/month), which was further reduced to 0 in April, 2020, that may be due to drastic change of air quality from moderate to very good. Interestingly, ration of $\mathrm{PM}_{2.5} / \mathrm{PM}_{10}$ was not varied much among the three sampling data. The ratio was 0.57 during 2018 sampling, which was changed to 0.68 in 2019 and in 2020 sampling, and the value was recorded as 0.65 . This value was well compared with the value obtained from some of the European cities like Barcelona (urban) recorded as 0.64; Finokalia, Greece (coastal) recorded as 0.63; and Milan (urban) recorded as 0.71 (Gerasopoulos et al. 2007; Marcazzan et al. 2003; Pey et al. 2008). Ratio of $\mathrm{PM}_{2.5}$ / $\mathrm{PM}_{10}$ generally gives an indication of the ambient air, because it is assumed that a high ratio is mainly due to presence of wind-borne dusts, unpaved road and less emission of fine particles due to various industrial activities (Khodeir et al. 2012; Mahapatra et al. 2013). When air speed was compared, there was low speed of air movement throughout the study period in three seasons, which varied from 10-30 kmph in 2020, 4-22 kmph in 2019 and 4-16 kmph in 2018 (Indian
Meteorological Department, MoES, India). This also suggests that reduction of different ambient parameters during lockdown may be the result of complete shutdown of all the activities of ship recycling at Alang ship recycling yard from March, 2020, to date of sample collected. In Alang, less variation of this ratio indicates that there is a state of equilibrium with respect to the air pollution. In 2018 and 2019, when recycling activities were in full swing, there was more vehicular movement as well as $\mathrm{PM}_{10}$ pollution; however, during the time of lockdown, both vehicular movement and recycling activities are reduced drastically, resulting no much shift in the ratio.

In case of average SPM values of 3 years of sampling, more than four-fold reduction of value was recorded in 2020 (Fig. $2 \mathrm{a})$, in comparison with the two previous years of sampling. Reduction of this value might be due to reduction of overall ambient air pollution; however, complete cessation of ship movement might be another reason. In a previous study, this was evidence in the pristine environment of Artic, where due to arrival of a passenger ship with capacity of 1600 passengers, the concentration of SPM was increased to 38-fold, when there were no other back ground pollution sources (Zhan et al. 2014).

\section{Gaseous pollutants}

When compared with two previous years of data, there is a significant reduction $(p<0.05)$ in the load of $\mathrm{SO}_{2}, \mathrm{NO}_{2}, \mathrm{NH}_{3}$ and $\mathrm{O}_{3}$ in the ambient air as was recorded in 2020 sampling when compared with the previous 2 years of sample data (Table 5, supplementary file). This might be due to the fact that ship cutting at high temperature using LPG torch and vehicle movements may contribute in generation of $\mathrm{NO} x$ and $\mathrm{SO}_{X}$, and the process of combustion produces $\mathrm{CO}_{2}$ and 
Table 3 Physicochemical characteristics of seawater observed during the study period at different locations

\begin{tabular}{|c|c|c|c|c|c|c|c|c|c|c|}
\hline Locations & & SW1 & SW2 & SW3 & SW4 & SW5 & Mean & STD & Max & Min \\
\hline \multirow[t]{3}{*}{ Temp. $\left({ }^{\circ} \mathrm{C}\right)$} & May 20 & 31 & 32 & 30 & 32 & 31 & 31 & 1 & 32 & 30 \\
\hline & January 19 & 22 & 20 & 21 & 22 & 22 & 22 & 1 & 22 & 20 \\
\hline & February 18 & 28 & 27 & 27 & 28 & 28 & 27 & 1 & 28 & 27 \\
\hline \multirow[t]{3}{*}{ TSS (mg/L) } & May 20 & 312 & 345 & 356 & 325 & 389 & 345 & 30 & 389 & 312 \\
\hline & January 19 & 376 & 400 & 396 & 403 & 403 & 396 & 11 & 403 & 376 \\
\hline & February 18 & 394 & 393 & 405 & 399 & 395 & 397 & 5 & 405 & 393 \\
\hline \multirow[t]{3}{*}{ Salinity (ppt) } & May 20 & 39 & 35 & 38 & 37 & 36 & 37 & 2 & 39 & 35 \\
\hline & January 19 & 35 & 37 & 37 & 38 & 37 & 37 & 1 & 38 & 35 \\
\hline & February 18 & 37 & 37 & 37 & 37 & 36 & 37 & 0 & 37 & 36 \\
\hline \multirow[t]{3}{*}{$\mathrm{pH}$} & May 20 & 7.5 & 7.6 & 8.1 & 8 & 7.6 & 7.76 & 0.27 & 8.1 & 7.5 \\
\hline & January 19 & 8.01 & 8.2 & 8.47 & 8.02 & 8.04 & 8.15 & 0.2 & 8.47 & 8.01 \\
\hline & February 18 & 7.9 & 7.85 & 7.95 & 7.95 & 7.85 & 7.9 & 0.05 & 7.95 & 7.85 \\
\hline \multirow[t]{3}{*}{ Turbidity (NTU) } & May 20 & 450 & 123 & 163 & 465 & 197 & 280 & 165 & 465 & 123 \\
\hline & January 19 & 310 & 312 & 256 & 323 & 289 & 298 & 27 & 323 & 256 \\
\hline & February 18 & 77 & 82 & 73 & 69 & 82 & 76 & 6 & 82 & 69 \\
\hline \multirow[t]{3}{*}{ DO (mg/L) } & May 20 & 4.8 & 4.5 & 4.2 & 4.5 & 4.3 & 4.5 & 0.2 & 4.8 & 4.2 \\
\hline & January 19 & 3.9 & 4.5 & 3.7 & 3.8 & 4.8 & 4.1 & 0.5 & 4.8 & 3.7 \\
\hline & February 18 & 3.6 & 7.2 & 1.2 & 5.6 & 6 & 4.7 & 2.4 & 7.2 & 1.2 \\
\hline \multirow[t]{3}{*}{ BOD (mg/L) } & May 20 & 3.7 & 3.5 & 3.7 & 3.1 & 3.2 & 3.4 & 0.3 & 3.7 & 3.1 \\
\hline & January 19 & 3.4 & 3.1 & 3.2 & 2.9 & 3.5 & 3.2 & 0.2 & 3.5 & 2.9 \\
\hline & February 18 & 2.8 & 6 & ND & 2.8 & 5 & 3.3 & 2.3 & 6 & 0 \\
\hline \multirow[t]{3}{*}{$\mathrm{NH}_{4}-\mathrm{N}(\mathrm{mg} / \mathrm{L})$} & May 20 & ND & ND & ND & ND & ND & ND & ND & ND & ND \\
\hline & January 19 & 0.5 & 0 & 0.7 & 0.85 & 3.3 & 1.07 & 1.29 & 3.3 & 0 \\
\hline & February 18 & 13.34 & 3.75 & 7.5 & 0.83 & 8.34 & 6.75 & 4.76 & 13.34 & 0.83 \\
\hline \multirow[t]{3}{*}{$\mathrm{NO}_{2}-\mathrm{N}(\mathrm{mg} / \mathrm{L})$} & May 20 & ND & ND & ND & ND & ND & ND & ND & ND & ND \\
\hline & January 19 & ND & ND & ND & ND & ND & ND & ND & ND & ND \\
\hline & February 18 & 0.24 & 0.12 & 0.24 & 0.42 & 0.48 & 0.3 & 0.15 & 0.48 & 0.12 \\
\hline \multirow[t]{3}{*}{$\mathrm{NO}_{3}-\mathrm{N}(\mathrm{mg} / \mathrm{L})$} & May 20 & 0.81 & 0.63 & 0.35 & 0.98 & 0.29 & 0.61 & 0.3 & 0.98 & 0.29 \\
\hline & January 19 & 11.95 & 8.7 & 6.75 & 13.3 & 8.7 & 9.88 & 2.67 & 13.3 & 6.75 \\
\hline & February 18 & 22.07 & 30.33 & 16.31 & 17.89 & 22.56 & 21.83 & 5.45 & 30.33 & 16.31 \\
\hline \multirow[t]{3}{*}{ Total-N (mg/L) } & May 20 & 0.81 & 0.64 & 0.35 & 0.98 & 0.29 & 0.61 & 0.3 & 0.98 & 0.29 \\
\hline & January 19 & 12.22 & 8.72 & 7.11 & 14.21 & 10.36 & 10.52 & 2.8 & 14.21 & 7.11 \\
\hline & February 18 & 22.09 & 30.33 & 16.32 & 17.89 & 22.57 & 21.84 & 5.45 & 30.33 & 16.32 \\
\hline \multirow[t]{3}{*}{$\mathrm{PO}_{4}-\mathrm{P}(\mathrm{mg} / \mathrm{L})$} & May 20 & ND & ND & ND & ND & ND & $\mathrm{ND}$ & ND & ND & ND \\
\hline & January 19 & ND & ND & ND & ND & ND & ND & ND & ND & ND \\
\hline & February 18 & ND & ND & ND & ND & ND & ND & ND & ND & $\mathrm{ND}$ \\
\hline \multirow[t]{3}{*}{ Silicate $(\mathrm{mg} / \mathrm{L})$} & May 20 & 88.04 & 68 & 94.71 & 93.5 & 98.36 & 88.52 & 12.05 & 98.36 & 68 \\
\hline & January 19 & 81.34 & 79.19 & 81.06 & 79.41 & 76.05 & 79.41 & 2.11 & 81.34 & 76.05 \\
\hline & February 18 & 51.43 & 51.21 & 68.07 & 52.89 & 49.75 & 54.67 & 7.57 & 68.07 & 49.75 \\
\hline \multirow[t]{3}{*}{$\mathrm{Cr}(\mu \mathrm{g} / \mathrm{L})$} & May 20 & ND & ND & ND & ND & ND & ND & ND & ND & ND \\
\hline & January 19 & 0.08 & 0.15 & 0.06 & 0.12 & 0.14 & 0.11 & 0.04 & 0.15 & 0.06 \\
\hline & February 18 & 0.27 & 0.29 & 0.3 & 0.28 & 0.34 & 0.29 & 0.03 & 0.34 & 0.27 \\
\hline \multirow[t]{3}{*}{$\mathrm{Mn}(\mu \mathrm{g} / \mathrm{L})$} & May 20 & ND & ND & 1 & 1 & ND & 1 & 0 & 1 & ND \\
\hline & January 19 & 0.58 & 0.46 & 0.26 & 0.29 & 1.06 & 0.53 & 0.32 & 1.06 & 0.26 \\
\hline & February 18 & 0.37 & 0.24 & 0.27 & 0.24 & 0.39 & 0.3 & 0.08 & 0.39 & 0.24 \\
\hline \multirow[t]{3}{*}{$\mathrm{Co}(\mu \mathrm{g} / \mathrm{L})$} & May 20 & ND & ND & ND & ND & ND & ND & ND & ND & ND \\
\hline & January 19 & ND & 0.03 & ND & 0.02 & ND & 0.02 & 0.02 & 0.03 & 0.02 \\
\hline & February 18 & 0.84 & 0.88 & 0.92 & 1.01 & 1.37 & 1 & 0.21 & 1.37 & 0.84 \\
\hline $\mathrm{Ni}(\mu \mathrm{g} / \mathrm{L})$ & May 20 & ND & ND & 1 & ND & ND & 1 & 0 & 1 & ND \\
\hline
\end{tabular}


Table 3 (continued)

\begin{tabular}{|c|c|c|c|c|c|c|c|c|c|c|}
\hline Locations & & SW1 & SW2 & SW3 & SW4 & SW5 & Mean & STD & Max & Min \\
\hline & January 19 & 1.21 & ND & 1.02 & ND & ND & 1.12 & 0.13 & 1.21 & 1.02 \\
\hline & February 18 & 1.75 & 1.57 & 1.76 & 1.02 & 1.87 & 1.59 & 0.34 & 1.87 & 1.02 \\
\hline \multirow[t]{3}{*}{$\mathrm{Cu}(\mu \mathrm{g} / \mathrm{L})$} & May 20 & 1 & ND & 1 & 1 & ND & 1 & 0 & 1 & ND \\
\hline & January 19 & ND & 0.04 & ND & ND & 0.04 & 0.04 & 0 & 0.04 & 0.04 \\
\hline & February 18 & 1.03 & 0.97 & 1.46 & 0.93 & 1.25 & 1.12 & 0.22 & 1.46 & 0.93 \\
\hline \multirow[t]{3}{*}{$\mathrm{Zn}(\mu \mathrm{g} / \mathrm{L})$} & May 20 & ND & ND & ND & ND & ND & ND & ND & ND & ND \\
\hline & January 19 & 5.25 & 6.32 & 5.32 & 1.25 & 2.35 & 4.1 & 2.18 & 6.32 & 1.25 \\
\hline & February 18 & 5.32 & 5.23 & 5.32 & 4.21 & 5.03 & 5.02 & 0.47 & 5.32 & 4.21 \\
\hline \multirow[t]{3}{*}{ As $(\mu \mathrm{g} / \mathrm{L})$} & May 20 & ND & ND & ND & ND & ND & ND & ND & ND & ND \\
\hline & January 19 & 0.12 & 0.13 & 0.15 & 0.13 & 0.14 & 0.13 & 0.01 & 0.15 & 0.12 \\
\hline & February 18 & 8.66 & 7.87 & 7.55 & 8.62 & 7.03 & 7.94 & 0.7 & 8.66 & 7.03 \\
\hline \multirow[t]{3}{*}{$\mathrm{Cd}(\mu \mathrm{g} / \mathrm{L})$} & May 20 & ND & ND & ND & ND & ND & ND & ND & ND & ND \\
\hline & January 19 & 0.25 & ND & 0.21 & ND & ND & 0.23 & 0.02 & 0.25 & 0.21 \\
\hline & February 18 & 0.36 & 0.39 & 0.38 & 0.27 & 0.27 & 0.33 & 0.06 & 0.39 & 0.27 \\
\hline \multirow[t]{3}{*}{$\mathrm{Pb}(\mu \mathrm{g} / \mathrm{L})$} & May 20 & ND & ND & ND & ND & ND & ND & ND & ND & $\mathrm{ND}$ \\
\hline & January 19 & ND & 0.42 & ND & 0.44 & ND & 0.43 & 0.01 & 0.44 & 0.42 \\
\hline & February 18 & 0.63 & 0.46 & 0.75 & 0.45 & 0.58 & 0.57 & 0.13 & 0.75 & 0.45 \\
\hline
\end{tabular}

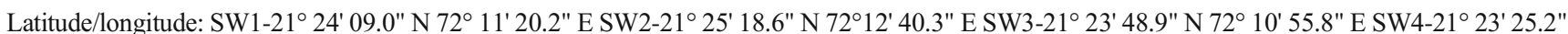
$\mathrm{N} 72^{\circ} 10^{\prime} 33.1^{\prime \prime} \mathrm{E} \mathrm{SW} 5-21^{\circ} 22^{\prime} 33.3^{\prime \prime} \mathrm{N} 72^{\circ} 10^{\prime} 01.0^{\prime \prime} \mathrm{E}$

$N D$ not detected

CO (Technical EIA Guideline Manual for Ship Breaking Yards, MoEF \& CC, PP:3-27). It was reported from the CPCB guideline for $\mathrm{NO}_{2}$ that there are two categories, i.e. good (sub-index 0-50) and satisfactory (51-100), and the breakpoint concentrations are fixed as $40 \mu \mathrm{g} / \mathrm{m}^{3}$ and $80 \mu \mathrm{g} /$ $\mathrm{m}^{3}$ (Akolkar 2016). In higher concentration of $\mathrm{NO}_{2}$ in air, there is all chance of asthma and chronic obstructive pulmonary diseases due to change in lung function (Organization et al. 2000). Present study reveals that values of $\mathrm{NO}_{2}$ are within the safe limit as prescribed in WHO report (Fig. 2b). Similarly, for $\mathrm{O}_{3}$, there are two categories i.e. good (sub-index $0-50)$ and satisfactory (51-100); the breakpoint concentrations are fixed as $50 \mu \mathrm{g} / \mathrm{m}^{3}$ and $100 \mu \mathrm{g} / \mathrm{m}^{3}$. All 3 years of data regarding in this ambient environment of Alang showed that the concentration of $\mathrm{O}_{3}$ was low and fell under good category. Further, due to complete absence of cutting activities, load of these pollutants might further be reduced in 2020 sampling.

\section{Heavy metals and PAH in ambient air}

Concentrations of selected heavy metals like $\mathrm{Ni}$ and $\mathrm{Pb}$ were studied from ambient air samples (Fig. 2c). Similar trends like other ambient air parameters were observed for these pollutants also. There is a significant $(p<0.05)$ reduction in the concentration of all the metals and benzene except arsenic, that was recorded in the May 2020 sampling. As there was a significant $(p<0.05)$ reduction in the $\mathrm{PM}_{10}$ value in May 2020 sampling, which may also reflect in the value of different heavy metals present in the ambient air. Because, filter paper used for $\mathrm{PM}_{10}$ is generally used for analysis of different heavy metals and benzene present in the ambient air. Further, cessation of different industrial activity and vehicular movement may also contribute in the reduction of in the selected heavy metals and benzene concentration in the ambient air.

The results obtained during the study were validated using analysis of variance (ANOVA), a single factor to know whether any significant difference is existing between different sampling years (May 2020, January 2019 and February 2018) with respect to mean for different parameters of air, seawater and sediment. A significant difference $(p<0.05)$ was observed between 3 years of data with respect to PM (PM10, PM2.5 and SPM), and the same were detailed in Table 5 (supplementary file). In all the PM, cases the $F$-values $\left(\mathrm{PM}_{10}-93.71\right.$; $\mathrm{PM}_{2.5}-17.16$ and SPM-141.73) were greater than the $F$-critical value i.e. 4.26 , with a $p$ value less than 0.05 , thereby resembling the existence of significant difference between 3 years with respect to each parameter. The analysis of variance showed the significance difference considering the entire 3 years data for each parameter; however, to know the significant difference between each pair (between 2 years data), we have to calculate the $t$-test separately. However, instead of calculating $t$ for each pair, the LSD has been calculated in order to draw a better insight about the observed data with a desired level of significance $(\alpha=0.05)$. In case of $\mathrm{PM}_{10}$, statistically significant differences were observed between three pairs (2020-2019, 
Table 4 PHc and heavy metals concentrations in sediments observed during the study period at different locations

\begin{tabular}{|c|c|c|c|c|c|c|c|c|}
\hline Location & & S1 & $\mathrm{S} 2$ & S3 & Mean & STD & Max & Min \\
\hline \multirow[t]{3}{*}{$\mathrm{PHc}(\mathrm{mg} / \mathrm{g})$} & May 20 & 0.03 & 0.02 & 0.03 & 0.03 & 0.01 & 0.03 & 0.02 \\
\hline & January 19 & 0.05 & 0.06 & 0.04 & 0.05 & 0.01 & 0.06 & 0.04 \\
\hline & February 18 & 0.04 & 0.05 & 0.04 & 0.04 & 0.01 & 0.05 & 0.04 \\
\hline \multirow[t]{3}{*}{$\mathrm{Al}(\mathrm{mg} / \mathrm{g})$} & May 20 & 0.15 & 0.21 & 0.13 & 0.16 & 0.04 & 0.21 & 0.13 \\
\hline & January 19 & 0.03 & 0.05 & 0.05 & 0.04 & 0.01 & 0.05 & 0.03 \\
\hline & February 18 & 2.41 & 2.47 & 2.47 & 2.45 & 0.03 & 2.47 & 2.41 \\
\hline \multirow[t]{3}{*}{$\mathrm{Cr}(\mathrm{mg} / \mathrm{g})$} & May 20 & ND & ND & ND & 0 & 0 & 0 & 0 \\
\hline & January 19 & 0.15 & 0.16 & 0.16 & 0.16 & 0.01 & 0.16 & 0.15 \\
\hline & February 18 & 0.26 & 0.26 & 0.3 & 0.28 & 0.02 & 0.3 & 0.26 \\
\hline \multirow[t]{3}{*}{$\mathrm{Mn}(\mathrm{mg} / \mathrm{g})$} & May 20 & 0.05 & 0.01 & 0.02 & 0.03 & 0.02 & 0.05 & 0.01 \\
\hline & January 19 & 1.64 & 1.66 & 1.63 & 1.64 & 0.02 & 1.66 & 1.63 \\
\hline & February 18 & 1.37 & 1.05 & 1.1 & 1.17 & 0.17 & 1.37 & 1.05 \\
\hline \multirow[t]{3}{*}{$\mathrm{Fe}(\%)$} & May 20 & 12.95 & 2.7 & 9.55 & 8.4 & 5.22 & 12.95 & 2.7 \\
\hline & January 19 & 21.25 & 20.05 & 20.15 & 20.48 & 0.67 & 20.25 & 20.05 \\
\hline & February 18 & 26.25 & 22.95 & 23.45 & 24.22 & 1.78 & 26.25 & 22.95 \\
\hline \multirow[t]{3}{*}{$\mathrm{Co}(\mathrm{mg} / \mathrm{g})$} & May 20 & ND & ND & ND & ND & ND & ND & ND \\
\hline & January 19 & 0.06 & 0.06 & 0.03 & 0.05 & 0.01 & 0.06 & 0.03 \\
\hline & February 18 & 0.05 & 0.04 & 0.06 & 0.05 & 0.01 & 0.06 & 0.04 \\
\hline \multirow[t]{3}{*}{ Ni (mg/g) } & May 20 & ND & ND & ND & ND & ND & ND & ND \\
\hline & January 19 & 0.07 & 0.09 & 0.1 & 0.08 & 0.01 & 0.1 & 0.07 \\
\hline & February 18 & 0.08 & 0.08 & 0.08 & 0.08 & 0 & 0.08 & 0.08 \\
\hline \multirow[t]{3}{*}{$\mathrm{Cu}(\mathrm{mg} / \mathrm{g})$} & May 20 & 0.01 & ND & 0.01 & 0.01 & 0 & 0.01 & ND \\
\hline & January 19 & 0.13 & 0.11 & 0.28 & 0.17 & 0.09 & 0.28 & 0.11 \\
\hline & February 18 & 0.16 & 0.25 & 0.14 & 0.18 & 0.06 & 0.25 & 0.14 \\
\hline \multirow[t]{3}{*}{$\mathrm{Zn}(\mathrm{mg} / \mathrm{g})$} & May 20 & 0.05 & ND & 0.03 & 0.03 & 0.02 & 0.05 & ND \\
\hline & January 19 & 0.29 & 0.26 & 0.21 & 0.25 & 0.04 & 0.29 & 0.21 \\
\hline & February 18 & 0.25 & 0.27 & 0.2 & 0.24 & 0.04 & 0.27 & 0.2 \\
\hline \multirow[t]{3}{*}{$\mathrm{Cd}(\mu \mathrm{g} / \mathrm{g})$} & May 20 & ND & ND & ND & ND & ND & ND & ND \\
\hline & January 19 & 0.35 & 0.02 & 0.34 & 0.24 & 0.19 & 0.35 & 0.02 \\
\hline & February 18 & 0.36 & 0.36 & 0.37 & 0.36 & 0 & 0.37 & 0.36 \\
\hline \multirow[t]{3}{*}{$\mathrm{Pb}(\mathrm{mg} / \mathrm{g})$} & May 20 & 0.01 & ND & ND & 0 & 0 & 0.01 & ND \\
\hline & January 19 & 0.03 & 0.02 & 0.03 & 0.02 & 0 & 0.03 & 0.02 \\
\hline & February 18 & 0.03 & 0.01 & 0.02 & 0.02 & 0.01 & 0.03 & 0.01 \\
\hline
\end{tabular}

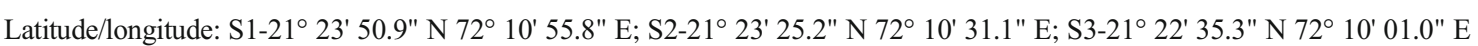

$N D$ not detected

2020-2018 and 2019-2018) with a difference of mean values (DMV) of $106.75,135.25$ and 28.50 greater than LSD value i.e. 24.60, respectively. However, for $\mathrm{PM}_{2.5}$ and SPM, one pair i.e. 2019-2018, the LSD value was observed to be greater than DMV resembling the existence of no significant difference (Table 6, supplementary file). In case of gaseous pollutants, significant $(p<0.05)$ differences were observed for $\mathrm{SO}_{2}$, $\mathrm{NO}_{2}, \mathrm{NH}_{3}$ and $\mathrm{O}_{3}$ with $F$-values of $241.19,502.26$ and 65.90 greater than $F$-critical value i.e. 4.26 (Table 5, supplementary file). However, for $\mathrm{SO}_{2}, \mathrm{NH}_{3}$ and $\mathrm{O}_{3}$, non-significant differences were observed for years 2019-2018, with LSD value greater than DMV (Table 6, supplementary file). For heavy metals and PAH concentration in air, significant differences were observed for years 2020-2018 (As), 2020-2019 (Ni), 2019-2018 (Pb) and 2020-2019 and 2020-2018 for benzene with DMV greater than LSD, respectively (Table 6, supplementary file).

\section{Air quality index}

Presenting the raw data sets of individual pollutant parameters and time series plots might not be enough to predict the air quality parameters of a particular location. It has been increasingly recognized that there is a need for simple, yet effective 


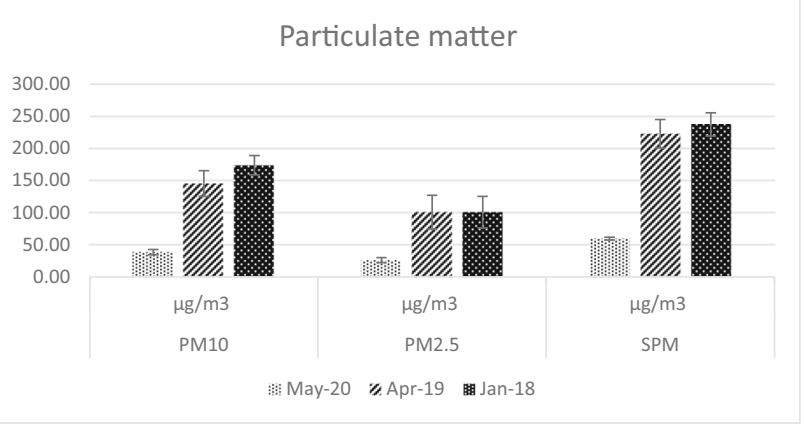

(a)

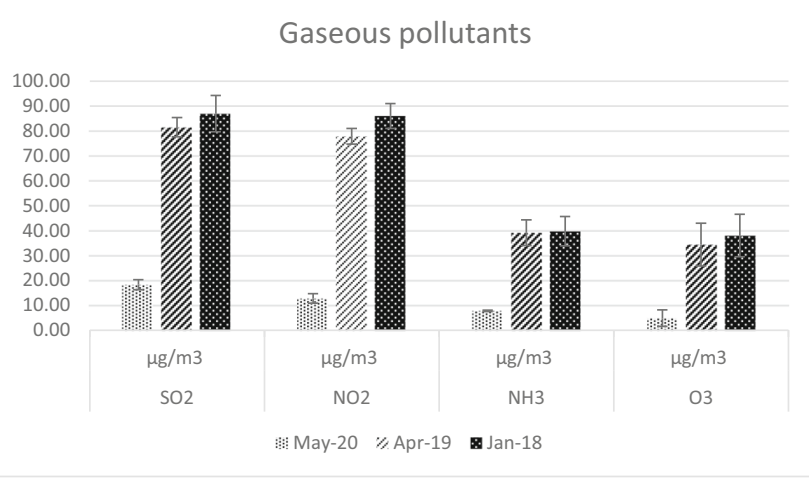

(b)

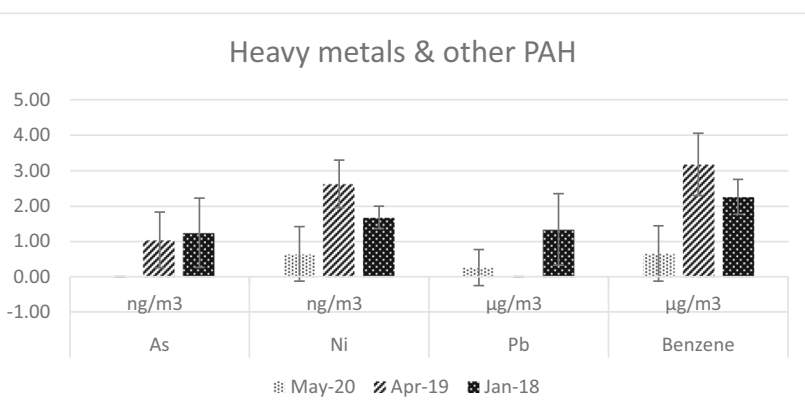

(c)

Fig. 2 Variation of ambient air pollutants observed during the study (a) particulate matter, (b) gaseous pollutants and (c) heavy metals and PAH

communication of ambient air quality in urban areas so as to enhance the awareness among the public, especially for those who suffer from illness caused by exposure to air pollution. Air quality index (AQI) is a tool for effective communication of air quality status of an area to people in terms, which are easy to understand and is used for decision making in many countries. It transforms complex air quality data of various pollutants into a single number (index value), nomenclature and colour, which fall in one of the six AQI categories, namely, good (0-50), satisfactory (51-100), moderately polluted (101-200), poor (201-300), very poor (301-400) and severe (401-500) with their associated health impacts. The Table 2 showed a distinct reduction of AQI value in 2020 sampling in comparison with the two previous years of sampling. However, apart from a particular station (A3), AQI value was moderate in previous years of sampling also.
However, considering the huge industrial activities and many precaution measures taken by different industrial bodies, AQI for Alang was mostly moderate during previous 2 years of sampling also. In lockdown sampling (January 20), it is consistently good.

\section{Seawater characteristics}

\section{Physicochemical characteristics}

Among different physicochemical parameters studied for three consecutive years (pre-lockdown, 2018-2019) and during lockdown (2020), it was observed that there is no significant $(p>0.05)$ change in the basic seawater parameters like DO and salinity (Table 3 ). There is no much variation of average BOD value of 3 years (Fig. 3a). BOD is usually proportional to the amount of organic matter present and therefore is a measure of the concentration of the biodegradable organic waste which principally include domestic sewage (Marske and Polkowski 1972). In Alang coastal water, the mean BOD value varied between 3.2 and $3.4 \mathrm{mg} / \mathrm{L}$ which indicate the water is moderately free from sewage contamination.

When we compare the nutrient parameters such as $\mathrm{NH}_{4}-\mathrm{N}$, $\mathrm{NO}_{2}-\mathrm{N}, \mathrm{NO}_{3}-\mathrm{N}$ and total- $\mathrm{N}$, there is statistically significant $(p$ $<0.05$ ) reduction in value in 2020 samples in comparison with the two previous years when all the industrial activities were in full swing. Different nutrients are mixed to the coastal water basically through non-point sources. However, domestic sewage mixing also plays a major role in increasing of different nutrient parameters. As the BOD value was almost constant for 3 years of samples, significant $(p<0.05)$ reduction of $\mathrm{NH}_{4}-\mathrm{N}, \mathrm{NO}_{2}-\mathrm{N}, \mathrm{NO}_{3}-\mathrm{N}$ and total- $\mathrm{N}$ value may be due to reduced activities of different industries located in the coast of Gulf of Khambhat and their reduced level of discharge through deep sea pipeline.

A significant difference $(p<0.05)$ was observed between 3 years of data with respect to all the physicochemical parameters of seawater except salinity, DO and BOD, and the same were detailed (Table 5, supplementary file). However, LSD has been calculated for in-depth analysis for all the physicochemical parameters. In case of $\mathrm{NH}_{4}-\mathrm{N}$ and $\mathrm{NO}_{2}-\mathrm{N}$, statistically significant differences were observed between two pairs (2020-2018 and 2019-2018) with a DMV value greater than LSD value (Table 7, supplementary file). In case of $\mathrm{pH}$, significant difference was observed only for 2020-2019 with a DMV value greater than LSD value.

\section{Heavy metal concentrations}

When comparison was made between present studies (consecutive 3 years) with some previous study carried out by Reddy et al. 2004, it was reported that heavy metal 


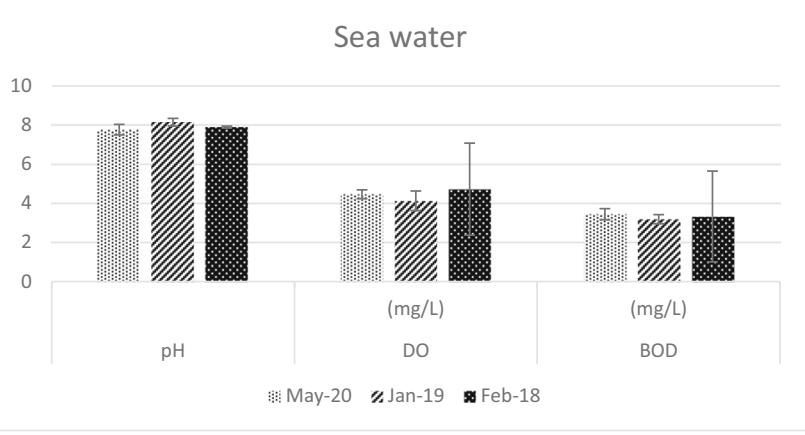

(a)

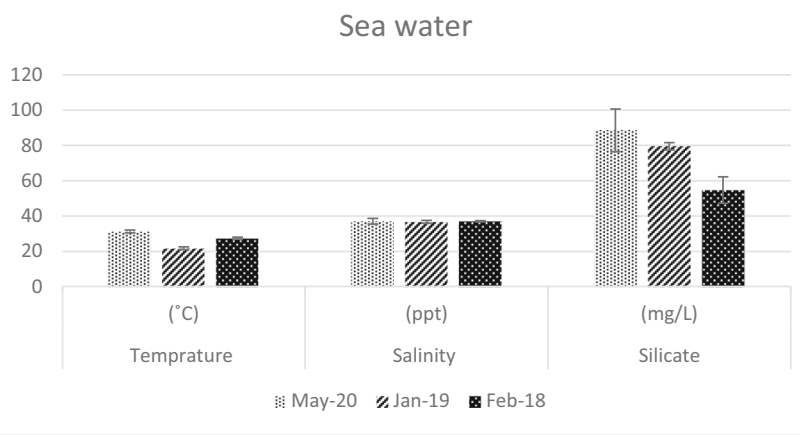

(b)

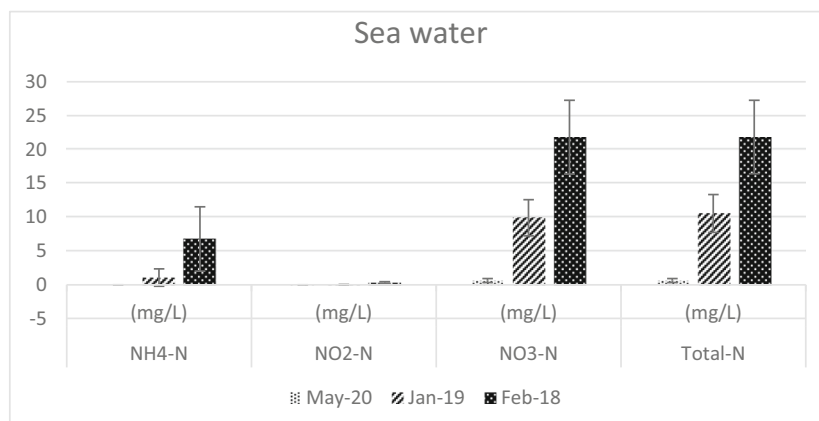

(c)

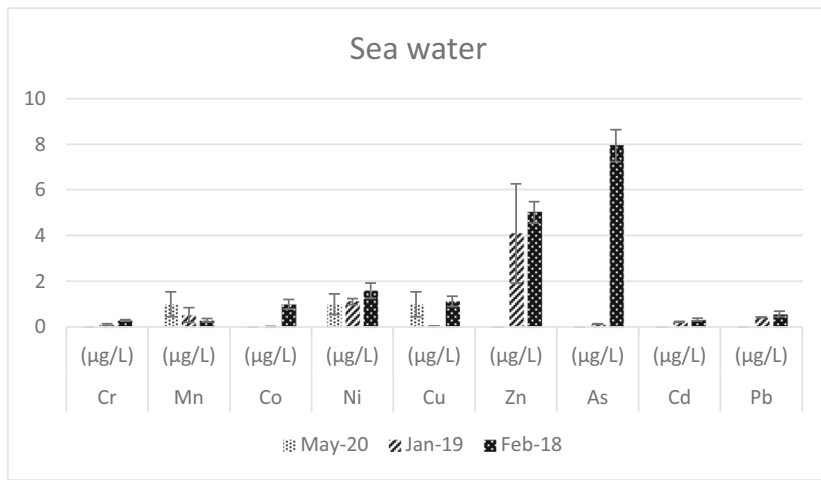

(d)

Fig. 3 Variation of seawater parameters observed during the study period a $\mathrm{pH}, \mathrm{DO}$ and BOD; $\mathbf{b}$ temperature salinity and silicate; $\mathbf{c}$ nitrogen; and $\mathbf{d}$ heavy metals

enrichment at Alang-Sosiya was relatively high. They described that the metals found at the highest concentration at Alang were iron $(13.7 \%)$, zinc $(0.12 \%)$ and manganese
$(0.46 \%)$. They also described that some other metals were almost 100 times more enriched compared with their natural, background level. However, after the development of dedicated treatment, storage and disposal facility in year 2006 and upgraded in 2011 by GMB, which consists landfill cells, effluent treatment plant and high temperature incinerator for management of downstream wastes generated from the ship recycling activities and further strict enforcement of 'Hazardous Waste Management Rules' by Gujarat Pollution Control Board (GPCB), there was a drastic reduction in the overall heavy metal pollution in the AlangSosiya coast. This reduction in the overall heavy metal concentration was observed in the data collected during 2018 and 2019 (Fig. 3d). Reduction of heavy metal concentration may also a partly result of upgradation of ship recycling plots. Around $70 \%$ ship recyclers have upgraded their plots in last 2 years by providing impervious floor complying 'Hong Kong International Convention 2009 (Puthucherril and Puthucherril 2010) for the Safe and Environmentally Sound Recycling of Ships'. It may be noted here that the HKC 2009 shall come into effect after 2 years from the fulfilment of the conditions; however, the majority of the ship recyclers at Alang upgraded their plots well in advance to curb the pollution from ship recycling activities.

It was observed that, after complete cessation of work for more than a couple of months in 2020, all the metal concentrations were further come down to negligible level (Fig. 3d). This is a very good indication to show how nature can purify their environment automatically in the absence of pollution inflow within few months of time. A significant difference $(p<0.05)$ was observed for all the heavy metals except Mn (Table 5, supplementary file). However, LSD has been calculated for in-depth analysis for all the heavy metals in seawater. In case of $\mathrm{Co}, \mathrm{Ni}, \mathrm{As}, \mathrm{Cd}$ and $\mathrm{Pb}$, no significant differences were observed for pair 2020-2019 with a DMV value less than LSD value (Table 7, supplementary file).

\section{Sediment characteristics}

PHc was only analysed for the sediment samples. It was observed that there was significant variation $(p<0.05)$ of total PHc concentration in the sediment samples collected in the 3 years of sampling. The value varied from 50 to $40 \mathrm{mg} / \mathrm{Kg}$ in 2018 and 2019, which was reduced to $30 \mathrm{mg} / \mathrm{Kg}$ in 2020 (Fig. 4). The results of PHc is compared with water quality standards for coastal waters for marine outfalls (Environment 1986), and it is within the permissible limit. Therefore, the sediment samples in the Alang area can be considered to be slightly impacted by the ship recycling activities. Further, it was also reported that, generally, there is a steady rise of the PHc concentration from summer to winter mainly because increase water and atmospheric temperature support the 
volatilization and microbial biodegradation process (Al-Saad et al. 2017; Maktoof et al. 2014) Slightly reduced value in 2020 might be due to less activities as well as the fact that the sampling was carried out during summer.

However, in the case of different heavy metal concentration in the sediments, a significant $(p<0.05)$ reduction in the concentration was observed after lockdown sampling during 2020. This reduction in heavy metal concentration especially for $\mathrm{Cr}, \mathrm{Cu}, \mathrm{Zn}, \mathrm{Cd}, \mathrm{Pb}$ is in line with the reduction of concentration found for seawater samples. Lead concentration was observed to be low during the study which is good as it is toxic in nature and gets entered in the food chain (Ferrans et al. 2021). This reduction may attribute majorly due to reduced activity in the ship recycling yard, which may reduce the accumulation of metals in the water as well as sediment samples. Apart from the common metals studied for both the water and sediments, some other metals were also analysed for sediment samples such as $\mathrm{Co}, \mathrm{Al}, \mathrm{Mn}$ and $\mathrm{Fe}$. Similar trend of significant $(p<0.05)$ reduction in concentration in 2020 sampling was recorded for these metals also. Present study which is carried out during the lockdown period would be the base for setting up the marine sediment norms for carrying out ship recycling activities using beaching method.

In a previous study carried out at ship breaking area of Bangladesh, it showed higher concentrations of Fe (11,932 to $41,362 \mu \mathrm{g} / \mathrm{kg})$ and $\mathrm{Pb}(36.78$ to $147.83 \mu \mathrm{g} / \mathrm{kg}$ ) in comparison with the Alang samples even during full activities in 2018 and 2019 (Siddiquee et al. 2012). In Alang, the concentration of Fe was reported to be much higher in 2001 in comparison with the value available in our present data in 2018 and 2019 (Tewari et al. 2001). This is mainly due to development of management of downstream waste management facility in 2006 and upgraded in 2011 by GMB for Alang Ship Recycling Yard and strict enforcement of Hazardous Waste Management laws by the competent authorities at Alang. During lockdown in Alang, the value further reduced significantly. Heavy metal exposure is a major concern during ship recycling activities. The pollutants released from a typical plate-cutting operation can potentially either affect workers directly by contaminating the breathing zone (air pollution) or can potentially add pollution load into the intertidal zone and contaminate sediments when pollutants get emitted in the secondary working zone and gets subjected to tidal forces (Deshpande et al. 2012). Due to complete halt of cutting activity, there was drastic reduction in the different heavy metal concentrations in both water and sediments (Fig. 4). The observed data were validated using analysis of variance (Table 5 , supplementary file), and statistical significant $(p<0.05)$ difference was observed for PHc and all the heavy metals considering the mean for 3 years. However, after calculating LSD for $\mathrm{PHc}, \mathrm{Fe}, \mathrm{Co}, \mathrm{Ni}, \mathrm{Cu}, \mathrm{Zn}, \mathrm{Cd}$ and $\mathrm{Pb}$, no significant difference was observed for pair 2019-2018 (Table 8, supplementary file).

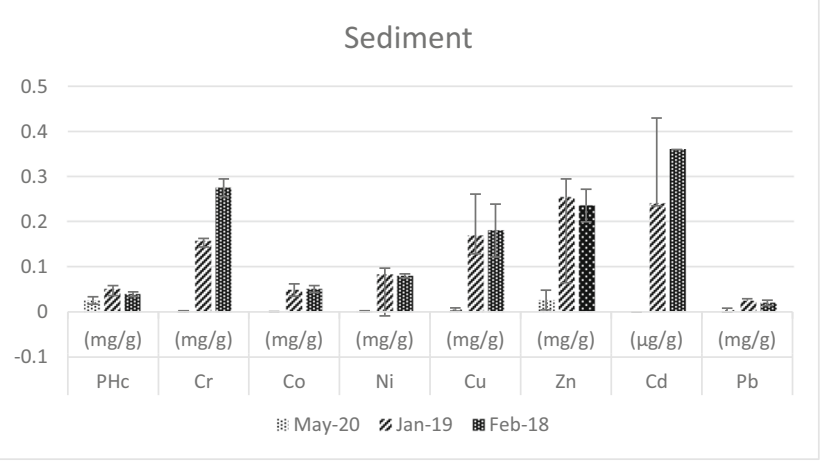

(a)

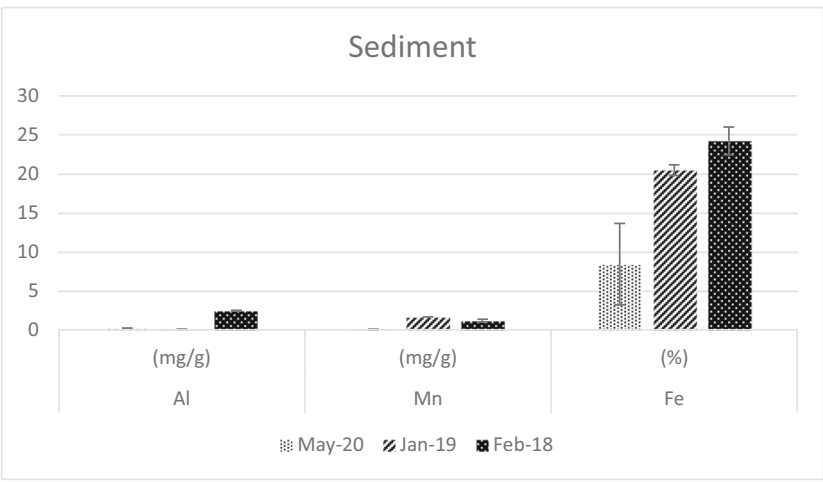

(b)

Fig. 4 Variation of PHc and heavy metals in sea sediments observed during the study period

\section{Biological parameters}

Phytoplankton is considered to be an important indicator for water pollution. According to the EU Water Framework Directive (WFD), phytoplankton is also determined as one of the biological quality elements for the classification of the ecological status of surface waters (Union 1994). Increase in nutrient input has a defined role in enhanced primary productivity by increasing phytoplankton production (Jaanus et al. 2009). In the present study, some of the diatom species like Coscinodiscus centralis, Chlorella sp., Unidentified sp. were reported only in lockdown samples in 2020 (Table 9, supplementary file). In a previous study by Tewari et al. 2001, high prevalence of Coscinodiscus was reported from Alang coast when the ship recycling activities were relatively low. Further, overall species diversity as well as SWDI was also high during 2020 sampling in comparison with the two previous years of sampling. It was already reported that SWDI value is a good indicator for pollution. Generally, SWDI value less than 1 indicates maximum impact of pollution, 1-2 indicate medium impact of pollution and more than 2 indicate the lowest or no impact of pollution (Kankal and Warudkar 2012). Average value of SWDI presented in this study indicates a higher value in both 2019 and 2020 (Fig. 5, supplementary file). But when comparison was done between 2019 and 2020, 2020 recorded further improvement. 
When average total bacterial counts of five sampling stations similar to the plankton were compared, it was observed that there is no significant change in the total bacterial counts. Similarly, Vibrio counts were also not significantly changed in the average samples collected pre lockdown $(2018,2019)$ and during lockdown (2020). The genus Vibrio is a genetically and ecologically diverse group of heterotrophic bacteria, which are ubiquitous in marine environments, especially in coastal areas (Zhang et al. 2018). Therefore, in the present study, no much variation was observed.

Bioaccumulation of heavy metal in the fish tissue is a good pollution indicator. Fish can assimilate the metals in different ways such as ingestion of particulate solid suspended from water, ingestion of feed they have taken, ion-exchange transversely into lipophilic tissue and adsorption on tissue and skin surface (Ahmed et al. 2016). Heavy metal accumulation study serves two purposes; in one way, it evaluates the possible risk in consumption of marine fish, and on the other hand, it gives an indication of metal pollution level in water (Ahmed et al. 2019). Therefore, in the present study, Mullet fish tissue was analysed for presence of selected heavy metals along with other sampling during lockdown (2020). Apart from Fe (34.9 ppm), $\mathrm{Zn}$ (18 ppm), $\mathrm{Pb}$ (1 ppm) and $\mathrm{Al}$ (13 ppm), other metals such as $\mathrm{Cr}, \mathrm{Ni}, \mathrm{Cu}$ and $\mathrm{Cd}$ were undetectable. In our previous study carried out in 2016, in the coastal catch of Mullet fish in Gulf of Khambat, higher concentration of $\mathrm{Pb}$ (24.08 ppm), Cd (8.25 ppm) and $\mathrm{Cu}$ (33.67 ppm) was reported (Raval et al. 2017). Therefore, it can be presumed that overall reduction in pollution load in water and sediments has impact reduction of metal bioaccumulation in the fish residing in the gulf water.

\section{Conclusion}

In the present study, attempt was made to understand the effect of complete lockdown in the world's biggest ship recycling yard on total environment including ambient, coastal water and coastal sediment. Attempt was also made to understand the decrease in metal bio-accumulation in the fish species (Mullet) catch from the nearby coastal environment. A significant reduction in the particulate matters $\left(\mathrm{PM}_{10}\right.$ and $\left.\mathrm{PM}_{2.5}\right)$ and different gaseous pollutants in the ambient air was recorded during lockdown sampling in comparison with sampling in 2018 and 2019 when recycling activities were going on in full swing. Similarly, there was drastic reduction in the majority of heavy metal concentration in the coastal water and sediments. This proves that the coastal environment has its efficient self-cleaning potentials. Further, this data also confirms that, in present practice along with $\mathrm{NH}_{4}-\mathrm{N}, \mathrm{NO}_{2}-\mathrm{N}, \mathrm{NO}_{3}-\mathrm{N}$ and total-N, the downstream waste management facility developed by GMB considerably reduced the impact of ship recycling activities at Alang. However, there are further scopes of improvement based on regular environment monitoring and drawing remedial measures for reduction of impact on marine environment.

Supplementary Information The online version contains supplementary material available at https://doi.org/10.1007/s11356-021-12885-y.

Acknowledgements Authors sincerely acknowledge Dr. S. Kannan, Director, CSIR-CSMCRI, for giving initial idea to undertake the work; Dr. Ankkur Goel for helping collection of IMD data; and Mr. Narsi Baraiya for field sampling. Manuscript published by Saraswat and Saraswat, Science 368 (6491), 594-595, also inspired the authors to undertake this work. Authors also sincerely acknowledge the Centralized Instrument Facility for analysis support of heavy metals from water and sediment samples. This manuscript has been assigned CSIR-CSMCRI$163 / 2020$ registration.

Author contribution All authors contributed to the study conception and design. Amit Chanchpara: data curation and writing-original draft. Vasavdutta Sonpal: data curation, review writing. Gauravkumar Mehta: review and editing. R.B. Thorat: review and editing. Sanak Ray: review, visualization, supervision and editing. Soumya Haldar: conceptualization, visualization, review, supervision and editing. All authors read and approved the manuscript.

Funding Institute funding

Data availability Not applicable

Declarations Ethics approval and consent to participate

The authors declare that they have no known competing financial interests or personal relationships that seem to affect the work reported in this article.

Consent for publication We do not have any individual person's data in any form.

Competing interests The authors declare that they have no conflict of interest.

\section{References}

Ahmed MK, Baki MA, Kundu GK, Islam MS, Islam MM, Hossain MM (2016) Human health risks from heavy metals in fish of Buriganga river, Bangladesh. Springerplus 5:1-12

Ahmed ASS, Rahman M, Sultana S, Babu SMOF, Sarker MSI (2019) Bioaccumulation and heavy metal concentration in tissues of some commercial fishes from the Meghna River Estuary in Bangladesh and human health implications. Mar Pollut Bull 145:436-447

Akolkar AMSB, 2016. National air quality index. Cent Pollut Control Board 1-44.

Al-Saad HT, Karem DS, Kadhim HA (2017) Total petroleum hydrocarbons in the soil of West Qurna-2 oil field Southern Iraq. Int J Mar Sci 7:51-58

APHA (2005) Standard methods for the examination of water and waste water, 21st edn. American Public Health Association, Washington

APHA (2017) Standard methods for the examination of water and waste water, 23rd edn. American Public Health Association, Washington

CPCB, 2013. Guidelines for the measurement of ambient air pollutants guidelines for manual sampling guidelines for manual sampling. 
Deshpande PC, Tilwankar AK, Asolekar SR (2012) A novel approach to estimating potential maximum heavy metal exposure to ship recycling yard workers in Alang, India. Sci Total Environ 438: 304-311. https://doi.org/10.1016/j.scitotenv.2012.08.048

Environment THE (1986) The environment (protection) rules , 1986. Environment 1986:1-10. https://doi.org/10.1017/ S0033291714000531

Ferrans L, Jani Y, Burlakovs J, Klavins M, Hogland W (2021) Chemical speciation of metals from marine sediments: assessement of potential pollution risk while dredging, a case study in southern sweden. Chemosphere. 263:128105

Gerasopoulos E, Koulouri E, Kalivitis N, Kouvarakis G, Saarikoski S, Mäkelä T, Hillamo R, Mihalopoulos N, 2007. Size-segregated mass distributions of aerosols over Eastern Mediterranean: seasonal variability and comparison with AERONET columnar sizedistributions.

Gordian ME, Ozkaynak H, Xue J, Morris SS, Spengler JD (1996) Particulate air pollution and respiratory disease in Anchorage, India. Environ Health Perspect 104:290-297

Haldar S, Mandal SK, Thorat RB, Goel S, Baxi KD, Parmer NP, Patel V, Basha S, Mody KH (2014) Water pollution of Sabarmati River - a Harbinger to potential disaster. Environ Monit Assess 186:22312242. https://doi.org/10.1007/s10661-013-3532-5

Hanson PJ, Evans DW, Colby DR, Zdanowicz VS (1993) Assessment of elemental contamination in estuarine and coastal environments based on geochemical and statistical modeling of sediments. Mar Environ Res 36:237-266

IS 5182 Part 2 Method of measurement of air pollution: sulphur dioxide. http://environmentclearance.nic.in/writereaddata/form $1 \mathrm{a} /$ homelinks/TGM_Ship\%20Breaking\%20Yards_010910_NK.pdf. Accessed 8 May 2020

Jaanus A, Toming K, Hällfors S, Kaljurand K, Lips I, 2009. Potential phytoplankton indicator species for monitoring Baltic coastal waters in the summer period, in: Eutrophication in Coastal Ecosystems. Springer, pp. 157-168.

Jena J, Ray S, Srichandan H, Das A, Das T (2013) Role of microorganisms in emission of nitrous oxide and methane in pulse cultivated soil under laboratory incubation condition. Indian J Microbiol 53: 92-99

Kankal NC, Warudkar S (2012) Biodiversity of phytoplankton, zooplankton and zoobenthos in east coast. Bay of Bengal near Nellore, Andhra Pradesh (India)

Khodeir M, Shamy M, Alghamdi M, Zhong M, Sun H, Costa M, Chen LC, Maciejczyk P (2012) Source apportionment and elemental composition of PM2. 5 and PM10 in Jeddah City, Saudi Arabia. Atmos Pollut Res 3:331-340

Kisan M, Sangathan S, Nehru J, Pitroda SG, 2006. Indian Standard Methods for measurement of air. Pollution, part 23: respirable suspended particulate maiter (PM 10), cyclonic flow technique.

Mahapatra PS, Ray S, Das N, Mohanty A, Ramulu TS, Das T, Chaudhury GR, Das SN (2013) Urban air-quality assessment and source apportionment studies for Bhubaneshwar, Odisha. Theor Appl Climatol 112:243-251

Maktoof AA, Al Khafaji BY, Al-janabi ZZ et al (2014) Evaluation of total hydrocarbons levels and traces metals in water and sediment from main outfall drain in Al-Nassiriya City/Southern Iraq. Nat Res Forum 5:795
Marcazzan GM, Ceriani M, Valli G, Vecchi R (2003) Source apportionment of PM10 and PM2. 5 in Milan (Italy) using receptor modelling. Sci. Total Environ 317:137-147

Marske DM, Polkowski LB (1972) Evaluation of methods for estimating biochemical oxygen demand parameters. J Water Pollut Control Fed 44:1987-2000

Organization WH et al (2000) Air quality guidelines for Europe

Pey J, Rodriguez S, Querol X, Alastuey A, Moreno T, Putaud JP, Van Dingenen R (2008) Variations of urban aerosols in the western Mediterranean. Atmos Environ 42:9052-9062

Puthucherril TG, Puthucherril TG, (2010). Appendix Hong Kong International Convention for the safe and environmentally sound recycling of ships, 2009. From Shipbreaking to Sustain. Sh Recycl. 210-256. https://doi.org/10.1163/ej.9789004174917.i-290. 38

Raval IH, Das KC, Haldar S (2017) Collection of mullet fish (Mugil cephalus) from west coast of India: evaluation of its quality with relation to food safety. Environ Sci Pollut Res 24:10833-10845

Ray S, Scholz M, Haritash AK (2019) Kinetics of carbon and nitrogen assimilation by heterotrophic microorganisms during wastewater treatment. Environ Monit Assess 191:451

Reddy MS, Basha S, Kumar VGS, Joshi HV, Ramachandraiah G (2004) Distribution, enrichment and accumulation of heavy metals in coastal sediments of Alang-Sosiya ship scrapping yard, India. Mar Pollut Bull 48:1055-1059

Saraswat R, Saraswat DA (2020) Research opportunities in pandemic lockdown. Science 368:594-595. https://doi.org/10.1126/science. abc3372

Siddiquee NA, Parween S, Quddus MMA, Barua P, 2012. Heavy metal pollution in sediments at ship breaking area of Bangladesh, in: Coastal Environments: Focus on Asian Regions. Springer, pp. 7887.

Tewari A, Joshi HV, Trivedi RH, Sravankumar VG, Raghunathan C, Khambhaty Y, Kotiwar OS, Mandal SK (2001) The effect of ship scrapping industry and its associated wastes on the biomass production and biodiversity of biota in in situ condition at Alang. Mar Pollut Bull 42:461-468

The Recycling of Ships Act (2019) Act No. 49 of 2019, 13th December, 2019. https://www.indiacode.nic.in/bitstream/123456789/15690/1/ AAA2019_49.pdf

Union, E, 1994. European Union 0067

USEPA, 1999. Compendium Method IO-3.1: Selection, preparation and extraction of filter material. Cent. Environ. Res. Inf. Off. Res. Dev. US Environ. Prot. Agency 1-30.

Viana M, Hammingh P, Colette A, Querol X, Degraeuwe B, de Vlieger I, Van Aardenne J (2014) Impact of maritime transport emissions on coastal air quality in Europe. Atmos Environ 90:96-105

Zhan J, Gao Y, Li W, Chen L, Lin H, Lin Q (2014) Effects of ship emissions on summertime aerosols at $\mathrm{Ny}-$ Alesund in the Arctic. Atmos Pollut Res 5:500-510

Zhang X, Lin H, Wang X, Austin B (2018) Significance of Vibrio species in the marine organic carbon cycle-A review. Sci China Earth Sci $61: 1357-1368$

Publisher's note Springer Nature remains neutral with regard to jurisdictional claims in published maps and institutional affiliations. 